ORIGINAL ARTICLE

\title{
Evaluation of the influence of different cooking pot types on the metallic elements content in edible chicken tissues by MIP OES
}

\author{
Avaliação da influência do tipo de panela empregado para \\ cocção sobre os teores de elementos metálicos em carne de \\ frango por MIP OES
}

\begin{abstract}
Náira da Silva Campos ${ }^{1 *}$ (1), Flávia Barbosa Magalhães Alvarenga², Céphora Maria Sabarense ${ }^{2}$, Marcone Augusto Leal de Oliveira1', Janaína Garcia Timm³, Mariana Antunes Vieira ${ }^{3}$, Rafael Arromba de Sousa ${ }^{1}$
\end{abstract}

\author{
${ }^{1}$ Universidade Federal de Juiz de Fora (UFJF), Instituto de Ciências Exatas, Departamento de Química, Juiz de \\ Fora/MG - Brasil \\ ${ }^{2}$ Universidade Federal de Juiz de Fora (UFJF), Instituto de Ciências Biológicas, Departamento de Nutrição, Juiz de \\ Fora/MG - Brasil \\ ${ }^{3}$ Universidade Federal de Pelotas (UFPel), Centro de Ciências Químicas, Farmacêuticas e Alimentos, Laboratório \\ de Metrologia Química (LabMeQui), Capão do Leão/RS - Brasil
}

*Corresponding Author: Náira da Silva Campos, Universidade Federal de Juiz de Fora (UFJF), Instituto de Ciências Exatas, Departamento de Química, Grupo Baccan de Química Analítica, Campus Universitário, Rua José Lourenço Kelmer, s/n, Bairro São Pedro, CEP: 36036-900, Juiz de Fora/MG - Brasil, e-mail:

nairacampos@ice.ufjf.br

Cite as: Campos, N. S., Alvarenga, F. B. M., Sabarense, C. M., Oliveira, M. A. L., Timm, J. G., Vieira, M. A., \& Sousa, R. A. (2020). Evaluation of the influence of different cooking pot types on the metallic elements content in edible chicken tissues by MIP OES. Brazilian Journal of Food Technology, 23, e2019308. https://doi.org/10.1590/1981-6723.30819

\begin{abstract}
This work describes the analysis of different chicken tissues (gizzard, heart, and liver) both raw and cooked with seasonings in different types of cooking pots (iron pot, , aluminum pot and hammered aluminum pot) commonly used in Brazil. The samples were decomposed using microwave-assisted digestion with diluted nitric acid; and the contents of $\mathrm{Al}, \mathrm{Ca}, \mathrm{Cu}, \mathrm{Fe}, \mathrm{Mn}$ and $\mathrm{Ni}$ were determined using Microwave Induced Plasma Optical Emission Spectrometry (MIP OES). The Fe content was also determined by Flame Atomic Absorption Spectrometry, and the comparison showed good accuracy of the method. The limits of quantification were below $0.011 \mathrm{mg} \mathrm{kg}^{-1}$, showing adequate detectability. Cooking in the different pots increased the ash and protein contents as well as decreased the moisture content. Box-plot and Principal Components Analysis showed that $\mathrm{Ca}$ and $\mathrm{Fe}$ contents present the largest variations in the samples, followed by $\mathrm{Al}$ and moisture. The variables $\mathrm{Al}, \mathrm{Cu}, \mathrm{Mn}, \mathrm{Ni}$, ash, and protein presented similar behavior after cooking in all different pots. In addition, liver cooked in both iron and hammered aluminum pots presented similar Fe contents, while gizzard and heart showed similar Ca contents.
\end{abstract}

Keywords: Chicken meat; Iron pot; Hammered aluminum pot; Aluminum pot; Metals; MIP OES. 


\section{Resumo}

Este trabalho descreve a análise de tecidos comestíveis de frango como coração, fígado e moela, crus e cozidos com temperos em diferentes panelas (panela de ferro, panela de alumínio e panela de alumínio batido) comumente utilizadas no Brasil. A digestão ácida assistida por radiação micro-ondas, com utilização de ácido nítrico diluído, foi empregada para decomposição das amostras. Os teores dos elementos metálicos $\mathrm{Al}, \mathrm{Ca}, \mathrm{Cu}, \mathrm{Fe}, \mathrm{Mn}$ e $\mathrm{Ni}$ foram determinados por Espectrometria de Emissão Óptica com Plasma Induzido por Micro-ondas. A comparação dos teores de Fe obtidos também por Espectrometria de Absorção Atômica em Chama mostrou uma boa exatidão do método. Os limites de quantificação para os analitos avaliados ficaram abaixo de $0,011 \mathrm{mg} \mathrm{kg}^{-1}$, mostrando detectabilidade adequada. As cocções das amostras nas diferentes panelas utilizadas promoveram um aumento dos teores de cinzas e proteínas e uma diminuição dos teores de umidade. A Análise de Componentes Principais e os diagramas de caixa mostraram que as variáveis Ca e Fe apresentaram as maiores variações entre as amostras, seguidas pelas variáveis $\mathrm{Al}$ e umidade. As variáveis $\mathrm{Al}, \mathrm{Cu}, \mathrm{Mn}, \mathrm{Ni}$, cinzas e proteínas apresentaram comportamento semelhante após a cocção nos três tipos de panela empregados. A amostra de fígado cozida tanto na panela de ferro quanto na panela de alumínio batido apresentou teores similares de $\mathrm{Fe}$, enquanto as amostras de coração e moela apresentaram teores similares de Ca após cocção nas mesmas panelas.

Palavras-chave: Carne de frango; Panela de ferro; Panela de alumínio batido; Panela de alumínio; Metais; MIP OES.

\section{Introduction}

Chicken meat is an important source of different and substantial nutrients such as proteins, vitamins, and minerals (Food and Agricutlure Organization of the United Nations, 2014). In addition, chicken meat has lower fat content than other types of meat, being adequate for a healthy diet (Menezes et al., 2018). Besides, chicken meat plays an important role in Brazilian agriculture and economy with high exportation rates (Associação Brasileira de Proteína Animal, 2016); its many uses in different meals and processed products include pâté, sausage and others (Souza et al., 2013).

The protein quality of chicken meat, as well as its nutritional value, can be influenced by thermal treatments applied to it (Deb-Choudhury et al., 2014; He et al., 2010; Menezes et al., 2018; Quintaes et al., 2004; Wen et al., 2015). Cooking processes are employed to improve digestibility, palatability, as well as to inhibit pathogen growth (Park \& Brittin, 2000; Perelló et al., 2008). Thermal treatments applied to protein-rich food can cause changes in proteins structure as well as changes in food's $\mathrm{pH}$, and its water retention ability.

During cooking process, the food is in contact with the pot and all the cookware used, thus migration of metallic elements may occur. The migration of metals from the cookware may be considered adequate when there are deficiencies in the diet, such as in some cases of anemia. On the other hand, this scene may also be of concern since the migration of both essential and toxic elements can randomly occur (Liao et al., 2018; Park \& Brittin, 2000; Perelló et al., 2008; Quintaes et al., 2004). Furthermore, the cooking of food may result in chemical changes such as weight gain or water losses, color alterations and texture changes due to denaturation of proteins (Silva et al., 2017; Goran et al., 2016).

Some authors reported the effect of thermal processing, such as freezing, storage under refrigeration, and different forms of cooking on food (Silva et al., 2017; Ferreira et al., 2007; Rosa et al., 2006). Most of these studies monitor changes in the nutritional composition of the samples by determining fat and protein modifications, for example. However, few works focused on the mineral element contents in meat after different thermal treatments (Ferreira et al., 2007; Gokhale \& Mahoney, 2014; Goran et al., 2016; He et al., 2010; Liao et al., 2018; Menezes et al., 2018; Perelló et al., 2008; Rosa et al., 2006), showing that the type of thermal processing may influence the metals concentrations in the samples, either increasing or decreasing their contents (Nunes et al., 2013). However, samples in those studies were cooked without seasonings and spices, differing from the usual home cooking. Additionally, the authors did not explore whether different 
cooking pots types influence both nutritional and metallic contents in the food. These approaches may provide new results and information to the field.

Metallic determinations in different samples is usually made by spectrometric techniques (Food and Agriculture Organization of the United Nations, 1999) such as Flame Atomic Absorption Spectrometry (F AAS), Graphite Furnace Atomic Absorption Spectrometry (GF AAS), Inductively Coupled Plasma-Atomic Emission Spectrometry (ICP OES) and Microwave Induced Plasma Optical Emission Spectrometry (MIP OES), which is a novel plasma technique for multi-element analysis. MIP OES has many advantages compared to flame-based spectrometric methods (F AAS and F AES). Its plasma is sustained by $\mathrm{N}_{2}$, which can be extracted from air using an N2 generator, improving the safety since no flammable gases and their cylinders are required. On the other hand, higher plasma temperatures compared to flame and graphite furnace allows carbide formation or refractive element determination. Therefore, MIP OES is a cheap, practical, fast, and environmental friendly technique recently employed for multi-element determination in different food matrices, including vinegars (Ozbek et al., 2016), cheese and other dairy products (Diniz et al., 2017; Ozbek \& Akman, 2016b; Williams et al., 2017), in addition to bread (Ozbek \& Akman, 2016a) and beer (Leão et al., 2018).

In this context, this work aimed to study the effect of different cooking pots on the contents of some nutritional components, such as moisture, protein and ash in chicken meat, as well as to evaluate whether metallic leaching ( $\mathrm{Al}, \mathrm{Ca}, \mathrm{Cu}, \mathrm{Fe}, \mathrm{Mn}$, and $\mathrm{Ni}$ ) from different cookware can be observed in chicken meat samples after a microwave-assisted acid digestion.

\section{Materials and methods}

\subsection{Apparatus and reagents}

All materials were washed with a neutral soap (Prolab), soaked in 10\% (m/v) nitric acid for 24 hours and then rinsed with deionized water prior to use. Ultrapure water was obtained using a Milli-Q System (Millipore, Bedford, MA, USA).

A $100 \mathrm{mg} \mathrm{L}^{-1}$ of a multielement standard solution for MIP OES containing $\mathrm{Al}, \mathrm{Ca}, \mathrm{Cu}, \mathrm{Fe}, \mathrm{Mn}$ and $\mathrm{Ni}$ (Sigma Aldrich, Germany) was used to prepare standard solutions for the MIP OES determinations. The calibration range employed for all analytes was 0.50 to $5.0 \mathrm{mg} \mathrm{L}^{-1}$. For F AAS determinations, a $1,000 \mathrm{mg} \mathrm{L}^{-1}$ of a Fe solution (Qhemis High Purity, Jundiai, SP, Brazil) was used to prepare standard solutions with concentrations between 0.5 and $4.0 \mathrm{mg} \mathrm{L}^{-1}$. The samples were accurately weighted using an analytical balance (ME 204, Metler Toledo, Columbus, OH, USA).

A microwave oven from Berghof (model SpeedWave Four, Eningen, BW, Germany) was used for the acid digestion employing $\mathrm{HNO}_{3} 65 \% \mathrm{~m} / \mathrm{v}$ P.A. (Vetec, Rio de Janeiro, RJ, Brazil), for total metals determination.

The materials used for the samples cooking were: a stove (Atlas, Instrutherm, São Paulo, SP, Brazil), liquefied gas (Supergasbras, model P13, Betim, MG, Brazil), infrared digital thermometer (Instrutherm, TI 860, São Paulo, SP, Brazil), garlic (Oishii, São Paulo, SP, Brazil), table salt (Cisne, Cabo Frio, RJ, Brazil), soybean oil (Soya, Rio Grande, RS, Brazil), wooden spoon and cooking pots made of iron, aluminum and hammered aluminum bought at a local grocery store.

For Fe determinations by F AAS, a Thermo Scientific atomic absorption spectrometer, model SOLAAR M5 (Thermo Scientific, China) equipped with deuterium background correction were used. A Fe hollow cathode lamp was employed as radiation source $(248.3 \mathrm{~nm})$ with $10 \mathrm{~mA}$ of electric current. The other instrumental conditions were optimized by using a standard solution in $\mathrm{HNO}_{3}$ media. Such conditions corresponded to a bandpass of $0.2 \mathrm{~nm}$, burner height of $7.0 \mathrm{~cm}$ and a gas mixture of air $/ \mathrm{C}_{2} \mathrm{H}_{2}\left(\mathrm{C}_{2} \mathrm{H}_{2}\right.$ rate: $1.2 \mathrm{~L} \mathrm{m^{-1 }}$ ). For the measurements of $\mathrm{Al}, \mathrm{Ca}, \mathrm{Cu}, \mathrm{Fe}, \mathrm{Mn}$ and $\mathrm{Ni}$, an atomic emission spectrometer with microwave-induced plasma, model MIP 4200 (Agilent Technologies, Melbourne, Australia), equipped with 
a double-pass cyclonic chamber and an inert flow blurring nebulizer (OneNeb) was employed. The nitrogen used to generate the plasma was supplied by an air compressor from Agilent (4107 Nitrogen Generator, Melbourne, Australia). The plasma gas flow rate was $20.0 \mathrm{~L} \mathrm{~min}^{-1}$ and the nebulization gas flow rate was $1.5 \mathrm{~L} \mathrm{~min}^{-1}$. Instrumental parameters such as nebulizer gas pressure and viewing position were automatically optimized, for each analyte separately, using the instrument software (MP Expert). The instrumental parameters employed by MIP OES analysis, such as wavelength, plasma viewing position and nebulizer flow are listed in Table 1.

Table 1. MIP OES instrumental parameters employed to determine $\mathrm{Al}, \mathrm{Ca}, \mathrm{Cu}, \mathrm{Fe}, \mathrm{Mn}$ and $\mathrm{Ni}$ in chicken meat samples.

\begin{tabular}{|c|c|c|c|}
\hline Element & $\begin{array}{c}\text { Wavelength } \\
(\mathbf{n m})\end{array}$ & $\begin{array}{c}\text { Plasma Viewing Position } \\
(\mathrm{mm})\end{array}$ & $\begin{array}{l}\text { Nebulizer flow } \\
\quad\left(\mathrm{L} \text { min }^{-1}\right)\end{array}$ \\
\hline $\mathrm{Al}$ & 396.152 & -10 & 1.00 \\
\hline $\mathrm{Ca}$ & 393.366 & 10 & 0.60 \\
\hline $\mathrm{Cu}$ & 324.754 & 0 & 0.60 \\
\hline $\mathrm{Fe}$ & 371.993 & 0 & 0.75 \\
\hline $\mathrm{Mn}$ & 403.076 & 0 & 0.85 \\
\hline $\mathrm{Ni}$ & 352.424 & 0 & 0.60 \\
\hline
\end{tabular}

Sample Acquirement and Cooking Methods.

Chicken meat samples acquired for this work included gizzard, heart, and liver. Amounts of $1,000 \mathrm{~g}$ of each kind of tissue were acquired from two different local stores, totaling 2,000 $\mathrm{g}$ for each sample. Then, the samples were separated into two different groups: raw and cooked (c.a. $200.0 \mathrm{~g}$ employing the different cooking pots).

The cooking pots were bought exclusively for this study and the selected types were iron pot (P1), aluminum pot (P2) and hammered aluminum pot (P3), which are common types of pots used in Brazil. The cookware was washed with water and neutral soap before use. The iron cooking pot required an additional step before its use and was performed as described in the literature (Campos et al., 2018). The samples were labeled with codes as follow: Gizzard raw and cooked on P1, P2, and P3: GR, GP1, GP2, and GP3, respectively; Heart raw and cooked on P1, P2, and P3: HR, HP1, HP2, and HP3, respectively; Liver raw and cooked on P1, P2, and P3: LR, LP1, LP2, and LP3, respectively.

A domestic cooking procedure, using seasonings and spices such as table salt and garlic, was simulated in the laboratory under controlled conditions as reported in previous work (Campos et al., 2018). The metal content was also measured in blank solutions $(\mathrm{N}=2)$ containing both the spices and the water employed for the cooking procedures.

These solutions were used to measure background concentrations of the analytes. Both raw and cooked samples were dried in a vacuum oven at $(70 \pm 1)^{\circ} \mathrm{C}$ for $72 \mathrm{~h}$, milled, placed in decontaminating plastic flasks and frozen at approximately $-50{ }^{\circ} \mathrm{C}$. All cookware was washed with neutral soap and dried at room temperature between the cooking of the samples. The use of abrasive products was also avoided. All procedures were made in authentic duplicates.

\subsection{Proximate composition analysis}

Some parameters of the chicken meat samples composition (raw and cooked) such as moisture, protein and ash contents were also evaluated based on official methods by Adolfo Lutz Institute of Brazil (Instituto Adolfo Lutz, 2008). Moisture content was determined by heating $2.000 \mathrm{~g}$ of each type of sample in a vacuum oven at $105{ }^{\circ} \mathrm{C}$ until obtaining a constant weight. The protein content was evaluated by using the Kjeldahl 
method. To determine ash content, $1.000 \mathrm{~g}$ of the samples was placed in a muffle furnace and the incineration was performed at $550{ }^{\circ} \mathrm{C}$ for $5 \mathrm{~h}$ until constant weight. All the measurements were made in authentic duplicates (Instituto Adolfo Lutz, 2008).

\subsection{Mineral determinations}

Total contents of metallic elements $(\mathrm{Al}, \mathrm{Ca}, \mathrm{Cu}, \mathrm{Fe}, \mathrm{Mn}$, and $\mathrm{Ni}$ ) were determined in the samples, raw and cooked, after acid digestion with $6.00 \mathrm{~mL}$ of a $7 \mathrm{M}$ solution of $\mathrm{HNO}_{3}$ using a microwave oven. After the digestion procedure, the samples were transferred to a volumetric flask and the volume was brought up to $25.00 \mathrm{~mL}$ with deionized water. Some parameters of this digestion method, such as accuracy, precision, limits of detection and quantification, were previously evaluated for Fe (Campos et al., 2018). The accuracy (Thompson et al., 2002) was evaluated by the determination of Fe contents in the samples by the spectrometry techniques, F AAS and MIP OES. MIP OES was employed to determine the other mineral contents. All the measurements were made in authentic duplicates.

Principal component analysis (Campos et al., 2014; Jolliffe \& Cadima, 2016) (PCA) was also performed to evaluate the mineral content and proximate composition profile of the data set, and to identify possible associations between the variables.

\section{Results and discussion}

\subsection{Proximate composition analysis}

Table 2 shows the content of moisture, protein, and ash determined in both raw and cooked chicken samples.

Table 2. Moisture, protein, and ash contents of the raw and cooked chicken samples.

\begin{tabular}{cccc}
\hline Sample & $\begin{array}{c}\text { Moisture } \\
\mathbf{( \% )}\end{array}$ & $\begin{array}{c}\text { Protein }^{\mathbf{a}} \\
\mathbf{( \% ) ~ w / w )}\end{array}$ & $\begin{array}{c}\text { Ash }^{\mathbf{a}} \\
\mathbf{( \% )} \mathbf{w})\end{array}$ \\
\hline GR & $79 \pm 1$ & $14 \pm 1$ & $0.73 \pm 0.05$ \\
\hline GP1 & $63 \pm 1$ & $18 \pm 1$ & $3.0 \pm 0.1$ \\
\hline GP2 & $63 \pm 1$ & $18 \pm 1$ & $3.3 \pm 0.1$ \\
\hline GP3 & $67 \pm 1$ & $17 \pm 1$ & $2.7 \pm 0.1$ \\
\hline HR & $70 \pm 3$ & $13 \pm 1$ & $0.85 \pm 0.07$ \\
\hline HP1 & $52 \pm 1$ & $15 \pm 1$ & $2.8 \pm 0.1$ \\
\hline HP2 & $57 \pm 1$ & $14 \pm 1$ & $2.5 \pm 0.1$ \\
\hline HP3 & $53 \pm 1$ & $17 \pm 1$ & $2.7 \pm 0.1$ \\
\hline LR & $77 \pm 3$ & $14 \pm 1$ & $1.1 \pm 0.1$ \\
\hline LP1 & $57 \pm 1$ & $18 \pm 1$ & $3.1 \pm 0.1$ \\
\hline LP2 & $63 \pm 1$ & $18 \pm 1$ & $2.5 \pm 0.4$ \\
\hline LP3 & $59 \pm 1$ & $20 \pm 1$ & $3.0 \pm 0.1$ \\
\hline
\end{tabular}

GR = Raw gizzard; GP1 = Gizzard cooked in iron (P1), GP2= Gizzard cooked in aluminum pot (P2). GP3= Gizzard cooked in hammered aluminum pot (P3). HR = Raw Heart; HP1 = Heart cooked in iron (P1), HP2 = Heart cooked in aluminum pot (P2). HP3= Heart cooked in hammered aluminum pot $(\mathrm{P} 3)$. LR $=$ Raw liver; $\mathrm{LP} 1=$ Liver cooked in iron $(\mathrm{P} 1), \mathrm{LP} 2=$ Liver cooked in aluminum pot $(\mathrm{P} 2)$. HP3= Liver cooked

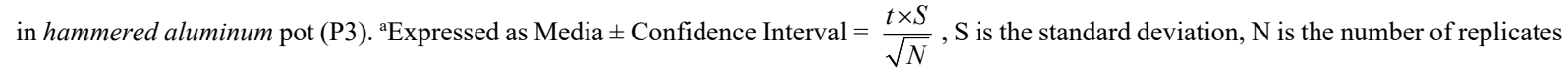
and $\mathrm{t}$ is the Student parameter. $(\alpha=0.05 ; \mathrm{n}=2)$. 
The levels found for these compounds in LR and HR corroborate with previously reported data (Universidade Estadual de Campinas, 2011). From the best of our knowledge, for gizzard and all cooked samples there are no data reported in the literature. In this sense, the results presented in this study may be employed in the nutritional area.

For raw and cooked gizzard samples, the moisture contents ranged from $63 \%$ to $79 \% \mathrm{w} / \mathrm{w}$, with a variation around $20 \%$, while for protein contents the obtained ranged from $14 \%$ to $18 \% \mathrm{w} / \mathrm{w}$, with a variation around $23 \%$. It is noteworthy that the samples cooking, regardless of the type of the cooking pot used, reduced the moisture content as well as an increased of the protein content. According to literature, the increase of ash and protein contents after cooking may be justified by the incorporation of the cooking media to the meat, as observed in this study. In addition, the samples cooking reduced the moisture levels and increased the dry matter concentration (Gokoglu et al, 2004; Rosa et al., 2006) For these two parameters, the variations observed from samples of different cooking pots were small $(<7 \%)$. On other hand, we observed an increase of approximately $79 \%$ of the ash contents after the cooking of these samples; however, and a moderate difference $(\sim 18 \%)$ between the samples from different cooking pots. Similar behavior was observed for heart and liver samples.

\subsection{Mineral determinations}

The use of diluted nitric acid for samples decomposition in routine analysis increased safety and is compatible with green chemistry principles and multi-element analysis (Castro et al., 2009; Gonzalez et al., 2009; Nóbrega et al., 2012). Additionally, lower blank values can be observed, which may result in lower limits of quantification that is good for regulatory purposes or trace element determination. The efficiency of diluted nitric acid solutions for digestion of different samples is well explained in the literature (Castro et al., 2009; Gonzalez et al., 2009; Nóbrega et al., 2012). However, to our best knowledge, there is no application for chicken tissues digestions cooked in the different cooking pots as reported in this study.

Table 3 shows some performance parameters obtained by MIP OES, such as the curve equations, linearity expressed by $\mathrm{R}^{2}$ and the limits of detection (LOD) and quantification (LOQ).

Table 3. Curve equations, Linearity, and Limits of Detection (LOD) and Quantification (LOQ) by MIP OES.

\begin{tabular}{cccc}
\hline Element & $\mathbf{R}^{\mathbf{2}}$ & $\begin{array}{c}\text { LOD } \\
(\mathbf{m g ~ k g}\end{array}$ & $\begin{array}{c}\mathbf{L O Q} \\
\left(\mathbf{m g ~ k g} \mathbf{~ g}^{-1}\right)\end{array}$ \\
\hline $\mathrm{Al}$ & 0.99180 & 0.054 & 0.18 \\
\hline $\mathrm{Ca}$ & 0.99550 & 0.0033 & 0.011 \\
\hline $\mathrm{Cu}$ & 0.99934 & 0.013 & 0.045 \\
\hline $\mathrm{Fe}$ & 0.99949 & 0.16 & 0.52 \\
\hline $\mathrm{Mn}$ & 0.99905 & 0.038 & 0.13 \\
\hline $\mathrm{Ni}$ & 0.99938 & 0.079 & 0.26 \\
\hline
\end{tabular}

$\mathrm{R}^{2}=$ determination coefficient

According to these parameters, this spectrometric technique showed good linearity (Barro Neto et al., 2007; Wood, 1999) since the $\mathrm{R}^{2}$ values are close to 1.000 for all analytes. Additionally, the values obtained for LOD and LOQ ranged between 0.0033 to $0.16 \mathrm{mg} \mathrm{kg}^{-1}$ and from 0.011 to $0.52 \mathrm{mg} \mathrm{kg}^{-1}$, respectively, that showed that the method has adequate detectability for the determination of the studied elements in chicken tissue samples.

To evaluate the accuracy of the method, the contents of Fe were also determined in the samples GR, GP1, HR, HP1, LR, and LP1, randomly selected. We used the Student's paired t-test to compare the concentrations 
obtained by F AAS and MIP OES techniques and no evidence of significant statistical differences were observed at $95 \%$ of significance $\left(t_{\text {calculated }}=0.7393<\right.$ table $\left.(5 ; 0.025)=2.571\right)$ (Barro Neto et al., 2007; Thompson et al., 2002). These results are shown in Table 4.

Table 4. Fe concentrations in some chicken meat samples obtained by F AAS and MIP OES.

\begin{tabular}{ccc}
\hline \multirow{2}{*}{ Sample } & \multicolumn{3}{c}{ Fe content $\left.\mathbf{( m g ~ k g}^{-1}\right)$} \\
\cline { 2 - 3 } & F AAS & MIP OES \\
\hline GR & $141 \pm 11$ & $143 \pm 8$ \\
\hline GP1 & $115 \pm 6$ & $109 \pm 6$ \\
\hline HR & $120 \pm 8$ & $138 \pm 2$ \\
\hline HP1 & $115 \pm 1$ & $129 \pm 1$ \\
\hline LR & $338 \pm 15$ & $321 \pm 9$ \\
\hline LP1 & $365 \pm 10$ & $464 \pm 2$ \\
\hline
\end{tabular}

$\overline{\mathrm{GR}}=$ Raw gizzard; GP1 = Gizzard cooked in iron (P1), HR = Raw Heart; HP1 = Heart cooked in iron $(\mathrm{P} 1), \mathrm{LR}=$ Raw liver; LP1 $=$ Liver cooked in iron (P1). ${ }^{a}$ Expressed as Media \pm Confidence Interval $=\frac{t \times S}{\sqrt{N}}, \mathrm{~S}$ is the standard deviation, $\mathrm{N}$ is the number of replicates and $\mathrm{t}$ is the Student parameter. $(\alpha=0.05 ; \mathrm{n}=2)$.

Since MIP OES is a multielemental technique (Diniz et al., 2017; Leão et al., 2018; Ozbek \& Akman, 2016a, 2016b; Ozbek et al., 2016; Williams et al., 2017) and the results obtained for $\mathrm{Fe}$ in the samples were statistically comparable with those obtained by F AAS, this technique was considered adequate to determine not only Fe but also other metallic elements, which concentrations should be easier detectable by MIP OES than by F AAS.

The concentrations of the $\mathrm{Al}, \mathrm{Ca}, \mathrm{Cu}, \mathrm{Fe}, \mathrm{Mn}$, and Ni obtained in the raw and cooked chicken samples are shown in Table 5.

Table 5. Minerals concentrations in chicken meat samples obtained by MIP OES.

\begin{tabular}{|c|c|c|c|c|c|c|}
\hline \multirow{2}{*}{ Sample } & \multicolumn{6}{|c|}{ Concentration $^{\mathrm{a}}\left(\mathrm{mg} \mathrm{kg}^{-1}\right)$} \\
\hline & Al & $\mathbf{C a}$ & $\mathbf{C u}$ & $\mathbf{F e}$ & Mn & $\mathbf{N i}$ \\
\hline GR & $55 \pm 1$ & $554 \pm 19$ & $4.1 \pm 0.1$ & $153 \pm 8$ & $3.7 \pm 0.1$ & $6.5 \pm 0.1$ \\
\hline GP1 & $1.2 \pm 0.2$ & $331 \pm 19$ & $4.4 \pm 0.3$ & $109 \pm 6$ & $2.5 \pm 0.1$ & $<\mathrm{LOD}^{\mathrm{b}}$ \\
\hline GP2 & $<$ LOD & $263 \pm 7$ & $4.2 \pm 0.2$ & $87.4 \pm 7.0$ & $1.8 \pm 0.1$ & $<$ LOD \\
\hline GP3 & $<$ LOD & $231 \pm 8$ & $11 \pm 1$ & $142 \pm 4$ & $1.1 \pm 0.2$ & $<$ LOD \\
\hline HR & $52 \pm 1$ & $459 \pm 15$ & $10 \pm 1$ & $138 \pm 2$ & $2.5 \pm 0.5$ & $6.3 \pm 0.1$ \\
\hline HP1 & $<$ LOD & $167 \pm 2$ & $9.4 \pm 0.3$ & $129 \pm 1$ & $1.4 \pm 0.1$ & $<$ LOD \\
\hline HP2 & $<$ LOD & $145 \pm 23$ & $10 \pm 1$ & $120 \pm 6$ & $0.73 \pm 0.13$ & $<$ LOD \\
\hline HP3 & $<$ LOD & $188 \pm 4$ & $11 \pm 1$ & $122 \pm 11$ & $0.80 \pm 0.04$ & $<$ LOD \\
\hline LR & $12 \pm 1$ & $596 \pm 20$ & $16 \pm 1$ & $321 \pm 9$ & $7.7 \pm 0.5$ & $<$ LOD \\
\hline LP1 & $<$ LOD & $326 \pm 21$ & $14 \pm 1$ & $464 \pm 2$ & $9.9 \pm 0.1$ & $<$ LOD \\
\hline LP2 & $3.8 \pm 0.9$ & $211 \pm 16$ & $12 \pm 1$ & $224 \pm 6$ & $8.0 \pm 0.1$ & $<$ LOD \\
\hline LP3 & $20 \pm 2$ & $304 \pm 22$ & $13 \pm 1$ & $313 \pm 3$ & $8.6 \pm 0.3$ & $<\mathrm{LOD}$ \\
\hline
\end{tabular}

GR = Raw gizzard; GP1 = Gizzard cooked in iron (P1), GP2= Gizzard cooked in aluminum pot (P2). GP3= Gizzard cooked in hammered aluminum pot (P3). HR = Raw Heart; HP1 = Heart cooked in iron $(\mathrm{P} 1), \mathrm{HP} 2=$ Heart cooked in aluminum pot $(\mathrm{P} 2)$. HP3= Heart cooked in hammered aluminum pot (P3). LR = Raw liver; LP1 = Liver cooked in iron (P1), LP2= Liver cooked in aluminum pot (P2), LP3= Liver cooked in hammered aluminum pot (P3). ${ }^{\mathrm{a} E x p r e s s e d}$ as Media \pm Confidence Interval $=\frac{t \times S}{\sqrt{N}}, \mathrm{~S}$ is the standard deviation, $\mathrm{N}$ is the number of replicates and $\mathrm{t}$ is the Student parameter. $(\alpha=0.05 ; \mathrm{n}=2)$. ${ }^{\mathrm{b}} \mathrm{LOD}=$ Limit of detection. For Ni LOD $=0.079 \mathrm{mg} \mathrm{kg}^{-1}$. 
The results for raw samples corroborates with other data previously reported (Franco, 1992; Universidade Estadual de Campinas, 2011). For gizzard samples, there is no data reported elsewhere, from the best of our knowledge. In general, we observed that the cooking process using different pots leads to more losses than increases of the metal elements determined in the chicken samples. Increases of Fe by cooking liver chicken may be noticed when using both iron and hammered aluminum pots.

During food cooking process, various reactions may change the food matrices. The use of different cooking methods including heat treatments and factors such as temperature, process duration and cooking medium cause chemical and physical changes that can modify the nutritional value of foods, mainly due to losses of vitamins and minerals. When food was cooked with water additions, water-soluble components can be lost by dissolution or leaching (Rosa et al., 2006).

Gerber, Scheeder and Wenk (Gerber et al., 2009) evaluated the effect of cooking on the levels of minerals, vitamins and fatty acids in beef, pork, and veal. In that study, the samples were grilled and cooked in water without the addition of seasonings. The authors observed an increase of around $16 \%$ of the total iron content and a decrease of $28 \%$ for calcium concentration. In both cases, the authors observed significant differences between the levels of these minerals found in raw pork samples and after the cooking methods.

Menezes and co-workers (Menezes et al., 2018) also verified the influence of five different heat treatments on the total and bioaccessible contents of minerals and proteins in beef, pork, and chicken. Regarding total contents, baked chicken and pork samples showed the largest calcium losses, which can be related to the break of chemical bonds between $\mathrm{Ca}$ and degraded protein. In addition, they showed that heating might affect bioaccessible fractions of some minerals and proteins. Using infrared spectroscopy, they also showed that denaturation of protein was associated with the bioaccessible fractions reduction.

In this context, the profile of our results are compatible with other data presented in the literature and, from the best of our knowledge, there is no work regarding the effect of these type of cooking pots on the contents of metallic elements in these edible chicken tissues.

\subsection{Statistical analysis}

Box-plot with results from MIP OES and proximate composition analysis are shown in Figures 1, 2 and 3 , for gizzard, heart and liver, respectively.
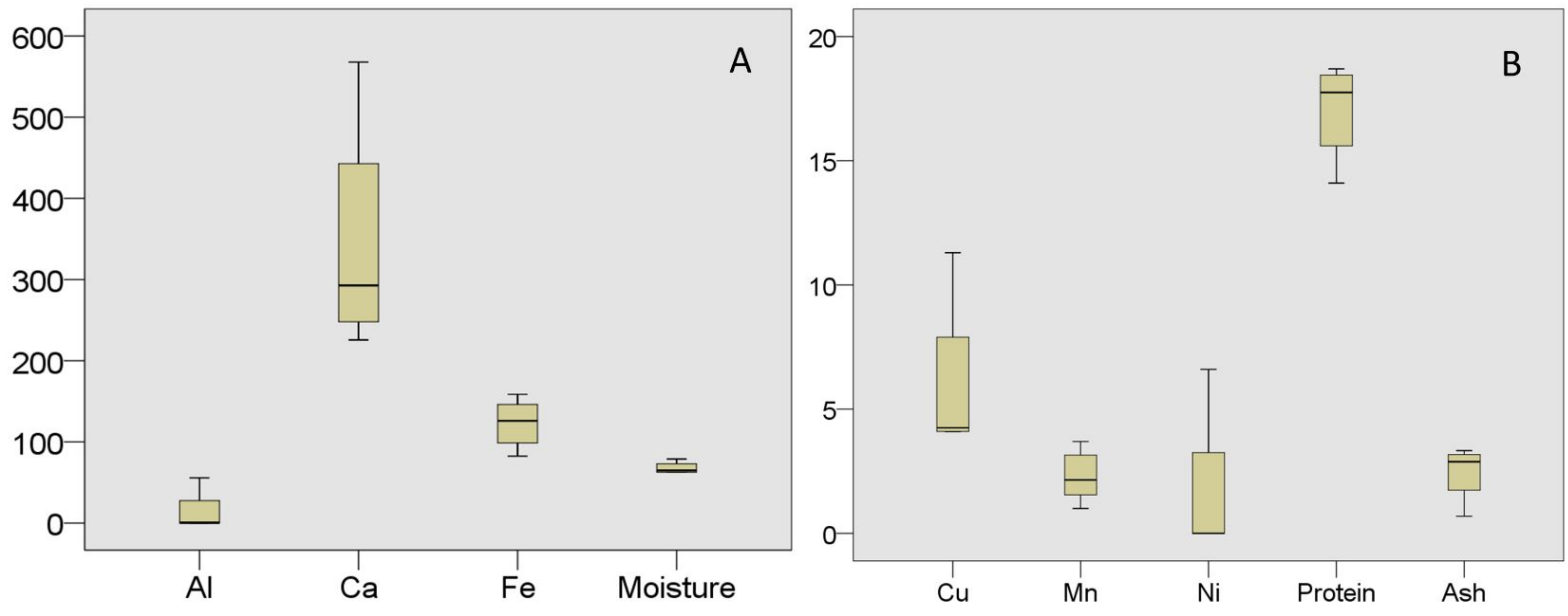

Figure 1. Box-plots with minerals and proximate composition analysis of gizzard. 

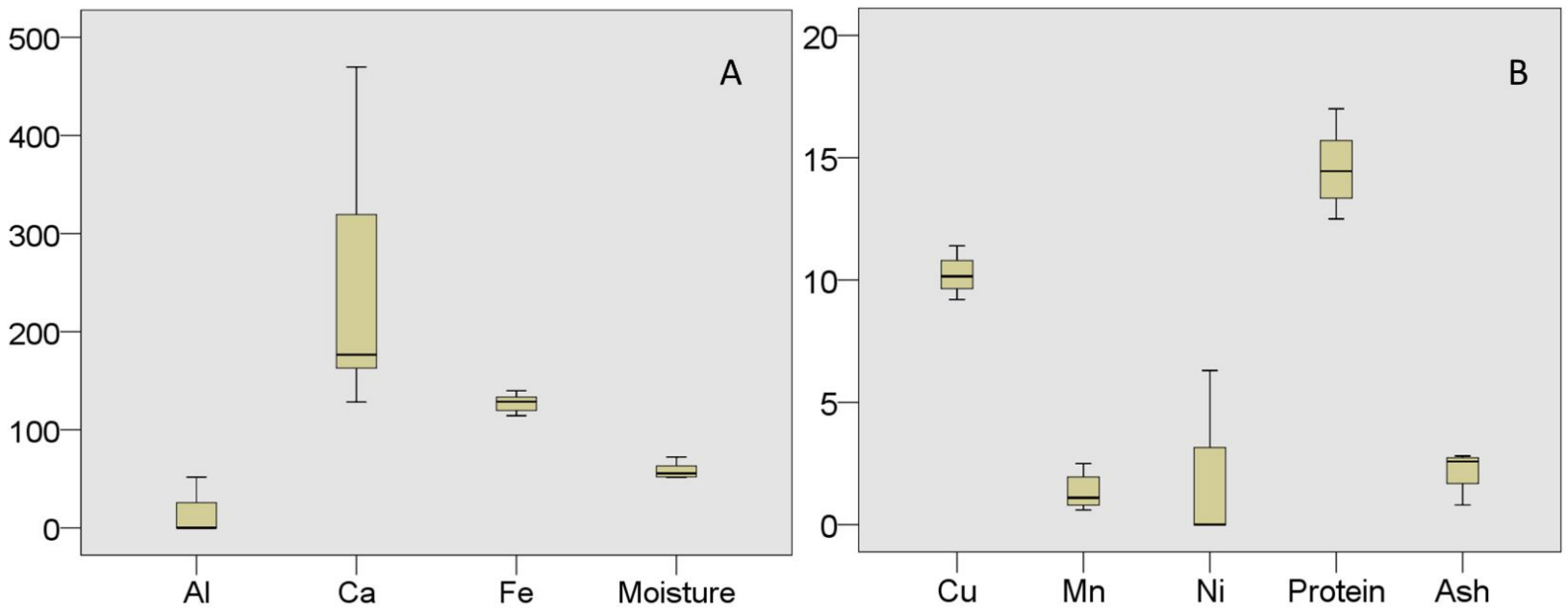

Figure 2. Box-plots with minerals and proximate composition analysis of heart.
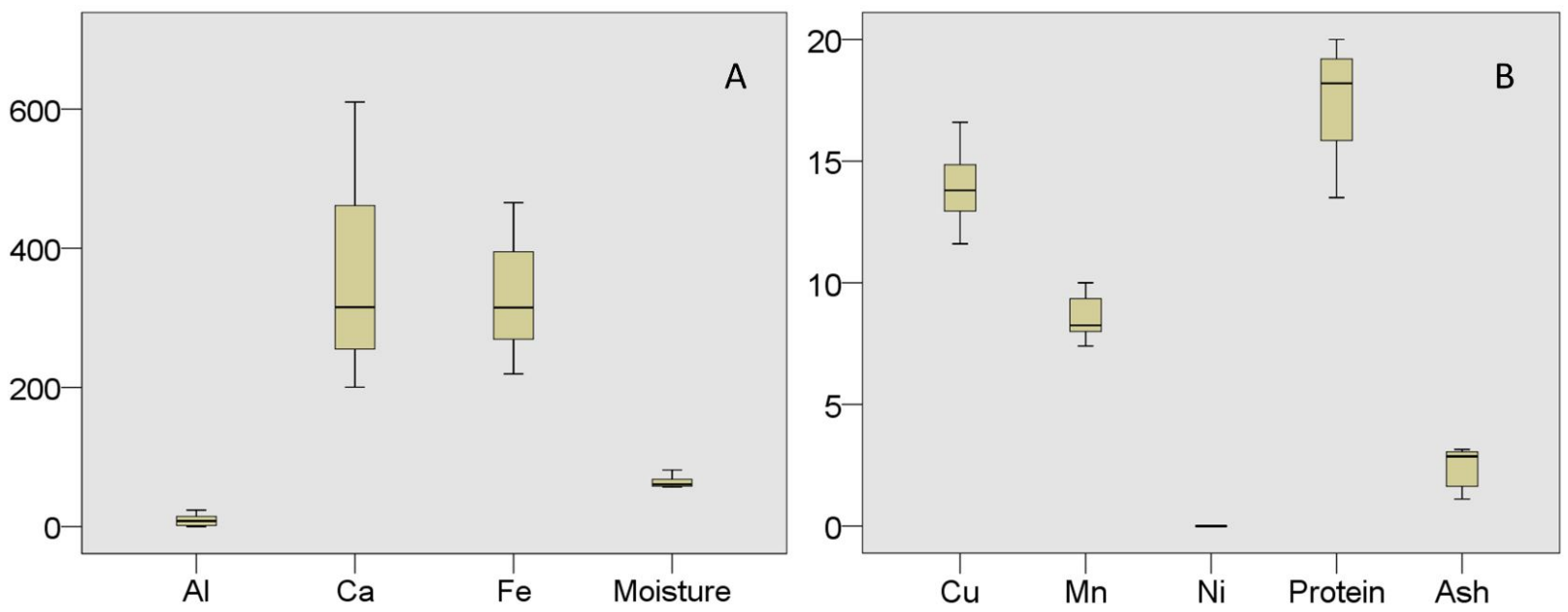

Figure 3. Box-plots with minerals and proximate composition analysis of liver.

By box-plots analysis, it can be noticed that $\mathrm{Ca}$ and $\mathrm{Fe}$ are the variables that present the largest variations around the averages for the three types of chicken tissues since they present the largest boxes. Next, $\mathrm{Al}$ and Moisture show a little variation around the average of data. On another hand, the variables $\mathrm{Al}, \mathrm{Cu}, \mathrm{Mn}, \mathrm{Ni}$, protein, and ash presented narrow concentration ranges, which may indicate a similar behavior for the different pots used.

Another approach employed to verify the influence of the cooking pot on the minerals concentrations in the chicken samples was an exploratory analysis by PCA, which is a chemometric tool based on a covariance model. We applied a correlation matrix of the contents (duplicates) of the variables (minerals and nutritional composition) and missing data (metals not detected) were replaced with zero (Ferreira, 2015; Barro Neto et al., 2007). The PCA obtained model showed a $99.41 \%$ explanation for the component's loadings PC1 $(68.93 \%)$ and PC2 $(30.48 \%)$ of the whole data variance. In Figure 4, four groups of samples can be observed in the Scores graphic (samples set) (a) and three groups can be seen in Loadings graphic (variables set) (b). 

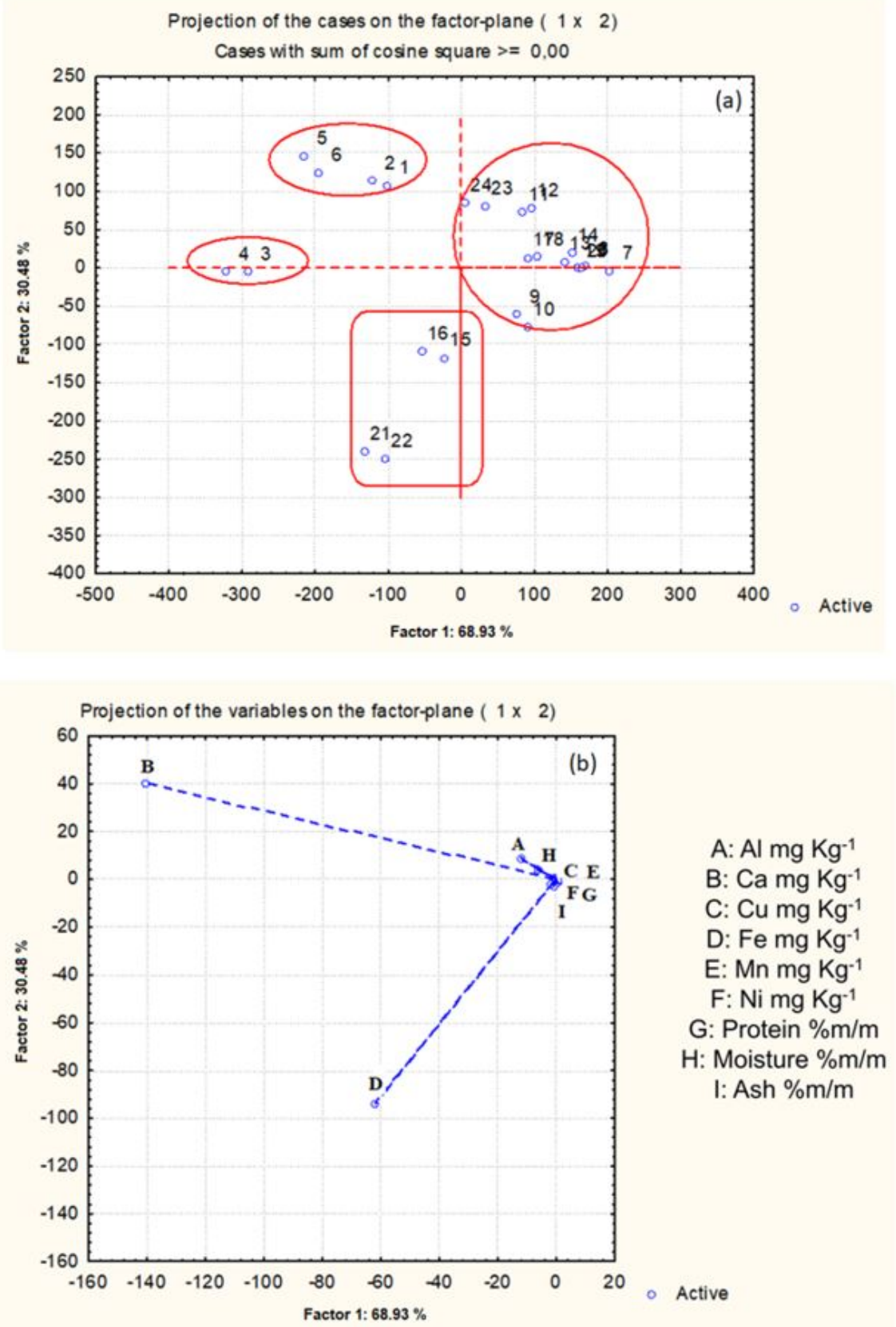

Figure 4. Scores (a) and Loadings (b) graphics obtained by PCA.

Analyzing these two plots combined, it can be observed that the LR sample $(3,4)$ is not influenced by the studied variables while the samples $\operatorname{HR}(1,2)$ and $\operatorname{GR}(5,6)$ are influenced by $\mathrm{Ca}$, that is, these two types of raw chicken meat samples present a similar profile of Ca contents. Besides, the samples LP3 $(15,16)$ e LP1 $(21,22)$ are influenced by the variable $\mathrm{Fe}$, in other words, the sample of liver cooked in the iron and in the hammered aluminum cooking pots present similar Fe concentrations. This result shows that these two types of cooking pots may provide similar levels of iron to this chicken tissue, and not only that one made of iron, as suggested by popular culture in Brazil (especially in Minas Gerais). 


\section{Conclusion}

In this study, we applied a laboratory simulated domestic cooking procedure to evaluate the influence of different cooking pots on the concentrations of metallic elements and nutritional composition of some types of chicken samples, such as gizzard, heart and liver. The samples were cooked using spices and three types of cooking pots usually employed in Brazil: iron pot, aluminum and hammered aluminum pot.

Regarding mineral determinations, it was observed that samples cooked in different pots showed different rates of migration of some metals. For liver cooked in hammered aluminum pot, for example, there was an increase of $40 \%$ of the $\mathrm{Al}$ contents when compared to raw liver, while a decrease of this analyte contents was observed from gizzard and heart samples. Additionally, $\mathrm{Ca}$ and $\mathrm{Fe}$ are the variables with largest contents variations, followed by Al and moisture. By Principal Components Analysis, it was possible to know that liver cooked in both iron and hammered aluminum cooking pots present similar Fe concentrations while raw gizzard and heart showed similar Ca profiles.

Additionally, it was observed an increase of ash and protein contents after cooking in the different pots employed as well a reduction of moisture levels due to dry matter concentration increase.

In general, it was observed that the cooking in the different pots leads to more losses than increases of the metallic elements determined in the chicken samples. Increases of Fe by cooking liver chicken may be reach using both iron and hammered aluminum pots.

\section{Acknowledgements}

The authors would like to thank the Fundação de Amparo à Pesquisa do Estado de Minas Gerais (FAPEMIG), Coordenação de Aperfeiçoamento Coordenação de Aperfeiçoamento de Pessoal de Nível Superior (CAPES) and Conselho Nacional de Desenvolvimento Científico e Tecnológico (CNPq). Additionally, the authors thank Dr. Aline Medina for assistance with MIP OES analysis and Dr. Anderson Schwingel Ribeiro for having encouraged to using MIP OES. We also thank Michele Nascimento for help with cooking methods, MSc. João Pablo Pereira, and Prof. Dr. Paulo Henrique Fonseca da Silva for the proximate composition analysis. The authors gratefully acknowledge MSc. Jefferson Martins for English revision.

\section{References}

Associação Brasileira de Proteína Animal - ABPA. (2016). Relatório anual. São Paulo: ABPA. Retrieved in 2018, February 15 , from http://abpa-br.com.br/files/publicacoes/c59411a243d6dab1da8e605be58348ac.pdf

Barro Neto, B., Scarmino, I. S., \& Bruns, R. E. (2007). Como fazer experimentos (3. ed.). Campinas: Editora Unicamp.

Campos, N. S., Lourdes, Â. M. F. O., Alvarenga, F. B. M., Sabarense, C. M., Oliveira, M. A. L., \& Sousa, R. A. (2018). Multivariate approach to assess in vitro Fe bioaccessibility in chicken meat. Food Science and Technology (Campinas), 38(1), 157-163. http://dx.doi.org/10.1590/1678-457x.01017

Campos, S. N., Oliveira, K. S., Almeida, R. M., Stephani, R., \& Oliveira, F. C. L. (2014). Classification of Frankfurters by FTRaman spectroscopy and chemometric methods. Molecules (Basel, Switzerland), 19(11), 18980-18992. PMid:25412044. http://dx.doi.org/10.3390/molecules191118980

Castro, J. T., Santos, E. C., Santos, W. P. C., Costa, L. M., Korn, M., Nóbrega, J. A., \& Korn, M. G. A. (2009). A critical evaluation of digestion procedures for coffee samples using diluted nitric acid in closed vessels for inductively coupled plasma optical emission spectrometry. Talanta, 78(4), 1378-1382. PMid:19362204. http://dx.doi.org/10.1016/j.talanta.2009.02.030

Deb-Choudhury, S., Haines, S., Harland, D., Clerens, S., van Koten, C., \& Dyer, J. (2014). Effect of cooking on meat proteins: mapping hydrothermal protein modification as a potential indicator of bioavailability. Journal of Agricultural and Food Chemistry, 62(32), 8187-8196. PMid:25033321. http://dx.doi.org/10.1021/jf502668w

Diniz, L. M. N., Carrasco, T. S., Medina, A. L., Ribeiro, A. S., \& Nunes, A. M. (2017). Use of MIP OES and F AAS/AES for determination of $\mathrm{Ca}$, k, na and $\mathrm{mg}$ in brazilian cream cheese. Quimica Nova, 40, 711-719. http://dx.doi.org/10.21577/01004042.20170049

Ferreira, M. M. C. (2015). Quimiometria. Campinas: Editora Unicamp. 
Ferreira, M. W., Bressan, M. C., Souza, X. R., Vieira, J. O. e., Faria, P. B., \& Andrade, P. L. (2007). Efeito dos métodos de cocção sobre a composição química e perfil lipídico de filés de Tilápia do Nilo (Oreochromis niloticus Linnaeus 1757). Ciência e Agrotecnologia, 31(3), 798-803. http://dx.doi.org/10.1590/S1413-70542007000300029

Food and Agriculture Organization of the United Nations - FAO (1999). Recommended Methods for Analysis and Sampling. Geneva: World Health Organization. CODEX STAN 2341999.

Food and Agricutlure Organization of the United Nations - FAO. (2014). Meat consumption. Rome: FAO. Retrieved in 2018, February 15, from http://www.fao.org/ag/againfo/themes/en/meat/background.html

Franco, G. (1992). Tabela de composição química dos alimentos (9. ed.). São Paulo: Editora Atheneu.

Gerber, N., Scheeder, M. R. L., \& Wenk, C. (2009). The influence of cooking and fat trimming on the actual nutrient intake from meat. Meat Science, 81(1), 148-154. PMid:22063975. http://dx.doi.org/10.1016/j.meatsci.2008.07.012

Gokhale, A. S., \& Mahoney, R. R. (2014). Cooking chicken breast reduces dialyzable iron resulting from digestion of muscle proteins. International Journal of Food Science, 2014, 1-6. PMid:26904627. http://dx.doi.org/10.1155/2014/345751

Gokoglu, N., Yerlikaya, P., \& Cengiz, E. (2004). Effects of cooking methods on the proximate composition and mineral contents of rainbow trout (Oncorhynchus mykiss). Food Chemistry, 84(1), 19-22. http://www.sciencedirect.com/science/article/pii/S0308814603001614

Gonzalez, M. H., Souza, G. B., Oliveira, R. V., Forato, L. A., Nóbrega, J. A., \& Nogueira, A. R. A. (2009). Microwave-assisted digestion procedures for biological samples with diluted nitric acid: identification of reaction products. Talanta, 79(2), 396-401. PMid:19559896. http://dx.doi.org/10.1016/j.talanta.2009.04.001

Goran, G. V., Tudoreanu, L., Rotaru, E., \& Crivineanu, V. (2016). Comparative study of mineral composition of beef steak and pork chops depending on the thermal preparation method. Meat Science, 118, 117-121. PMid:27088876. http://dx.doi.org/10.1016/j.meatsci.2016.03.031

He, M., Ke, C.-H., \& Wang, W.-X. (2010). Effects of cooking and subcellular distribution on the bioaccessibility of trace elements in two marine fish species. Journal of Agricultural and Food Chemistry, 58(6), 3517-3523. PMid:20192204. http://dx.doi.org/10.1021/jf100227n

Instituto Adolfo Lutz - IAL. (2008). Métodos físico-químicos para análise de alimentos. São Paulo: IAL.

Jolliffe, I. T., \& Cadima, J. (2016). Principal component analysis: a review and recent developments. Philosophical Transactions of the Royal Society A. Mathematical, Physical and Engineering Sciences, 374(2065), 1-16. https://doi.org/10.1098/rsta.2015.0202

Leão, P. R. P. d., Medina, A. L., Vieira, M. A., \& Ribeiro, A. S. (2018). Decomposição de amostras de cerveja com sistema de refluxo para determinação monoelementar por F AAS/AES e determinação multielementar por MIP OES. Brazilian Journal of Food Technology, 21, 1-11. http://dx.doi.org/10.1590/1981-6723.6217

Liao, W., Wang, G., Li, K., \& Zhao, W. (2018). Change of arsenic speciation in shellfish after cooking and gastrointestinal digestion. Journal of Agricultural and Food Chemistry, 66(29), 7805-7814. PMid:29953224. http://dx.doi.org/10.1021/acs.jafc.8b02441

Menezes, E. A., Oliveira, A. F., França, C. J., Souza, G. B., \& Nogueira, A. R. A. (2018). Bioaccessibility of Ca, Cu, Fe, Mg, Zn, and crude protein in beef, pork and chicken after thermal processing. Food Chemistry, 240, 75-83. PMid:28946338. http://dx.doi.org/10.1016/j.foodchem.2017.07.090

Nóbrega, J. A., Pirola, C., Fialho, L. L., Rota, G., Campos Jordão, C. E. K. M. A., \& Pollo, F. (2012). Microwave-assisted digestion of organic samples: how simple can it become? Talanta, 98, 272-276. PMid:22939159. http://dx.doi.org/10.1016/j.talanta.2012.06.079

Nunes, A. M., Sousa, R. A., da Silva, C. S., Peixoto, R. R. A., Vieira, M. A., Ribeiro, A. S., \& Cadore, S. (2013). Fast determination of $\mathrm{Fe}, \mathrm{Mg}, \mathrm{Mn}, \mathrm{P}$ and $\mathrm{Zn}$ in meat samples by inductively coupled plasma optical emission spectrometry after alkaline solubilization. Journal of Food Composition and Analysis, 32(1), 1-5. http://dx.doi.org/10.1016/j.jfca.2013.08.004

Ozbek, N., \& Akman, S. (2016a). Method development for the determination of calcium, copper, magnesium, manganese, iron, potassium, phosphorus and zinc in different types of breads by microwave induced plasma-atomic emission spectrometry. Food Chemistry, 200, 245-248. PMid:26830585. http://dx.doi.org/10.1016/j.foodchem.2016.01.043

Ozbek, N., \& Akman, S. (2016b). Microwave plasma atomic emission spectrometric determination of Ca, $\mathrm{K}$ and $\mathrm{Mg}$ in various cheese varieties. Food Chemistry, 192, 295-298. PMid:26304350. http://dx.doi.org/10.1016/j.foodchem.2015.07.011

Ozbek, N., Koca, M., \& Akman, S. (2016). A practical method for the determination of Al, B, Co, Cr, Cu, Fe, Mg, Mn, Pb, and Zn in different types of vinegars by microwave induced plasma optical emission spectrometry. Food Analytical Methods, 9(8), 22462250. http://dx.doi.org/10.1007/s12161-016-0421-x

Park, J., \& Brittin, H. C. (2000). Iron content, sensory evaluation, and consumer acceptance of food cooked in iron utensils. Journal of Food Quality, 23(2), 205-215. http://dx.doi.org/10.1111/j.1745-4557.2000.tb00207.x

Perelló, G., Martí-Cid, R., Llobet, J. M., \& Domingo, J. L. (2008). Effects of various cooking processes on the concentrations of arsenic, cadmium, mercury, and lead in foods. Journal of Agricultural and Food Chemistry, 56(23), 11262-11269. PMid:18986150. http://dx.doi.org/10.1021/jf802411q

Quintaes, K. D., Amaya-Farfan, J., Tomazini, F. M., Morgano, M. A., \& Mantovani, D. M. B. (2004). Migração de minerais de panelas brasileiras de aço inoxidável, ferro fundido e pedra-sabão (esteatito) para simulantes de alimentos. Food Science and Technology (Campinas), 24(3), 397-402. http://dx.doi.org/10.1590/S0101-20612004000300017 
Evaluation of the influence of different cooking pot types on the metallic elements content in edible chicken tissues by MIP OES Campos, N. S. et al.

Rosa, F. C., Bressan, M. C., Bertechini, A. G., Fassani, É. J., Vieira, J. O., Faria, P. B., \& Savian, T. V. (2006). Efeito de métodos de cocção sobre a composição química e colesterol em peito e coxa de frangos de corte. Ciência e Agrotecnologia, 30(4), 707-714. http://dx.doi.org/10.1590/S1413-70542006000400017

Silva, D. C. F., Arruda, A. M. V., \& Goncalves, A. A.-O. (2017). Quality characteristics of broiler chicken meat from free-range and industrial poultry system for the consumers. Journal of Food Science and Technology, 54(7), 1818-1826. https://doi.org/10.1007/s13197-017-2612-x

Souza, S. N. P., Nascentes, C. C., \& Costa, L. M. (2013). Validation of a microwave-assisted digestion procedure of pate samples using diluted $\mathrm{HNO} 3$ for Fe and Zn determination by FS FAAS. Analytical Methods, 5(22), 6411-6415. http://dx.doi.org/10.1039/c3ay41343h

Thompson, M., Ellison Stephen, L. R., \& Wood, R. (2002). Harmonized guidelines for single-laboratory validation of methods of analysis (IUPAC Technical Report). Pure and Applied Chemistry, 74, 835-855.

Universidade Estadual de Campinas - UNICAMP. (2011). Tabela Brasileira de Composição de Alimentos - TACO (4. ed.). Campinas: UNICAMP/NEPA.

Wen, S., Zhou, G., Li, L., Xu, X., Yu, X., Bai, Y., \& Li, C. (2015). Effect of cooking on in vitro digestion of pork proteins: a peptidomic perspective. Journal of Agricultural and Food Chemistry, 63(1), 250-261. PMid:25420116. http://dx.doi.org/10.1021/j5505323g

Williams, C. B., Wittmann, T. G., McSweeney, T., Elliott, P., Jones, B. T., \& Donati, G. L. (2017). Dry ashing and microwaveinduced plasma optical emission spectrometry as a fast and cost-effective strategy for trace element analysis. Microchemical Journal, 132, 15-19. http://dx.doi.org/10.1016/j.microc.2016.12.017

Wood, R. (1999). How to validate analytical methods. Trends in Analytical Chemistry, 18(9), 624-632.

http://dx.doi.org/10.1016/S0165-9936(99)00150-8

Funding: Fundação de Amparo à Pesquisa do Estado de Minas Gerais under grant CEX-APQ-01665-12. 